\title{
THE USE OF INFORMATION RESOURCES IN THE INTRODUCTION OF AGRICULTURAL PRODUCT CLASSIFICATION SYSTEMS IN BULGARIA
}

\author{
Roumen Otouzbirov \\ Trakia University, Students Town, Stara Zagora 6000, Bulgaria \\ roumen@uni-sz.bg
}

\begin{abstract}
Agricultural production is in need of an effective information system as far as requirements, marketing standards, prices and control are concerned. This system is one of the major prerequisites for achieving high quality and good competitiveness on the home and international markets. The aim of the current research is to study the information resources used in the introduction of the EU regulations for the classification of agricultural products in Bulgaria. The research is based on a questionnaire conducted among 40 people involved in the production and processing of agricultural products. The questions are concerned with the source of business and the size of the agricultural enterprise; whether or not the staff are aware of the EU regulations; the use of information sources (at least five should be ticked by the interviewee on completing the questionnaire and numbered in accordance with the degree of importance attached); what kind of information is missing; and who are the employees directly responsible for collecting information. Both comparative and descriptive analyses have been used in processing the empirical data that has been collected. As a result the following general conclusions have been arrived at: Representatives of micro- and small business enterprises, which comprise $75 \%$ of the interviewees, are not well informed of the EU regulations and requirements for the classification of agricultural products. The ministries in charge, as well as the state institutions, which are the most valued sources of information, do not seem willing to engage themselves in quick and effective exchange of information, in organizing training and counseling programs to facilitate the implementation of the EU requirements. Meanwhile, public organizations and specialized research institutes remain highly underestimated as information sources.
\end{abstract}

The desire for competitiveness and international market realization is impeded by the lack of a specialized information resource for agricultural produce enterprises.

Key words: information resources; classification systems; agricultural products

\section{КОРИСТЕЊЕ НА ИЗВОРИТЕ НА ИНФОРМАЦИИ КАКО ВОВЕД ВО ЗЕМЈОДЕЛСКИТЕ ПРОИЗВОДНИ КЛАСИФИКАЦОНИ СИСТЕМИ ВО БУГАРИЈА}

\footnotetext{
Земјоделското производство има потреба од ефективен информативен систем кој би вклучувал маркетиншки стандарди, цени и контрола. Овој систем е еден од најважните предуслови за постигнување висок квалитет и добра конкурентност на домашните и меѓународни пазари. Целта на истражувањето беше да се проследат изворите на информации содржани во воведот на регулативите на ЕУ во однос на класификација на земјоделските производи во Бугарија. Истражувањето се базираше на анкетата спроведена кај 40 лица вклучени во производството и преработката на земјоделските производи. Прашањата се однесуваа на: изворите на бизнисот и големината на земјоделските претпријатија, без разлика дали персоналот е запознаен или не со регулативите на ЕУ; употребата на информациони извори (за интервјуирање избрани најмалку пет, а во прашалникот подредени согласно со степенот на важноста); каков вид информација недостига; кои се вработените кои се директно одговорни за прибирање информации. При обработката на прибраните емпириски податоци се употребени и компаративната и описната анализа. Како резултат дојдовме до следните генерални заклучоци: - Претставници на микро и мали бизнис-компании, кои претставуваат $75 \%$ од испитаниците, не се баш добро информирани за регулативите на ЕУ и за барањата за класификација на земјоделските производи. - Се добива впечаток дека ресорните министерства, како и државните институции кои се највалидни извори на информации, не се ангажираат доволно во брза и ефективна размена на информации, во организирање обука и советодавни програми за имплементирање на барањата на ЕУ. Истовремено како извори на информации
} 
високо потценети остануваат јавните организации и специјализираните истражувачки институции. - Недостигот на специјализирани извори на информации за земјоделски производни претпријатија влијае врз желбата за конкурентност и реализација на меѓународниот пазар.

Клучни зборови: информативни ресурси; класификациски системи; земјоделски производи

\section{INTRODUCTION}

The introduction and implementation of the EU systems for classification of agricultural products with estimation scales and specific prices is a prerequisite for achieving both high quality and good competitiveness on home and international markets. In this line of thought what agricultural production needs is an effective information system reflecting the EU requirements, marketing standards, prices and control. Producers and manufacturers should be aware of the kind of products the market needs, the way to present these products, how to protect them and what their actual price is.

The social and economic effect of the implementation of the EU requirements for food safety is undoubtedly one of the most current issues in agricultural economics and practice today (Kovacheva, 2008a; Koteva et al., 2009; Malamova, 2009a). Researches indicate that the presence of information resources is a leading factor in the adequate and effective application of the EU standards in the agrarian sector (Kovacheva, 2008b; Malamova, 2009b).

The aim of the research is to study the information resources used in the introduction of the EU regulations for the classification of agricultural products in Bulgaria.

\section{MATERIALS AND METHODS}

The research is based on a questionnaire conducted among 40 people involved in the produc- tion and processing of agricultural products. The interviewees have been randomly selected among the visitors of two agrarian exhibitions in the cities of Stara Zagora and Plovdiv. The questions are concerned with the source of business and the size of the agricultural enterprise; whether or not the staff are aware of EU regulations; the use of information sources (at least five should be ticked by the interviewee on completing the questionnaire and numbered in accordance with the degree of importance attached); what kind of information is missing; and who are the employees directly responsible for collecting information. Both comparative and descriptive analyses have been used in processing the empirical data that has been collected.

The conducted questionnaire is one of the activities on a scientific project at the Faculty of Economics, Trakia University, Stara Zagora. The major focus of the project is the study of social and economic aspects of agricultural product classification systems.

\section{RESULTS AND DISCUSSION}

The collected data indicates that as far as the type of business is concerned (Fig. 1), the greatest number of interviewees (17) are producers of agricultural products $-42.5 \%$; 8 people, or $20.0 \%$, work in processing enterprises. Those involved in mixed enterprises (of both producing and processing nature) make up to $37.5 \%$ of interviewees, which is indicative that such enterprises still play an important role in the agrarian sector.

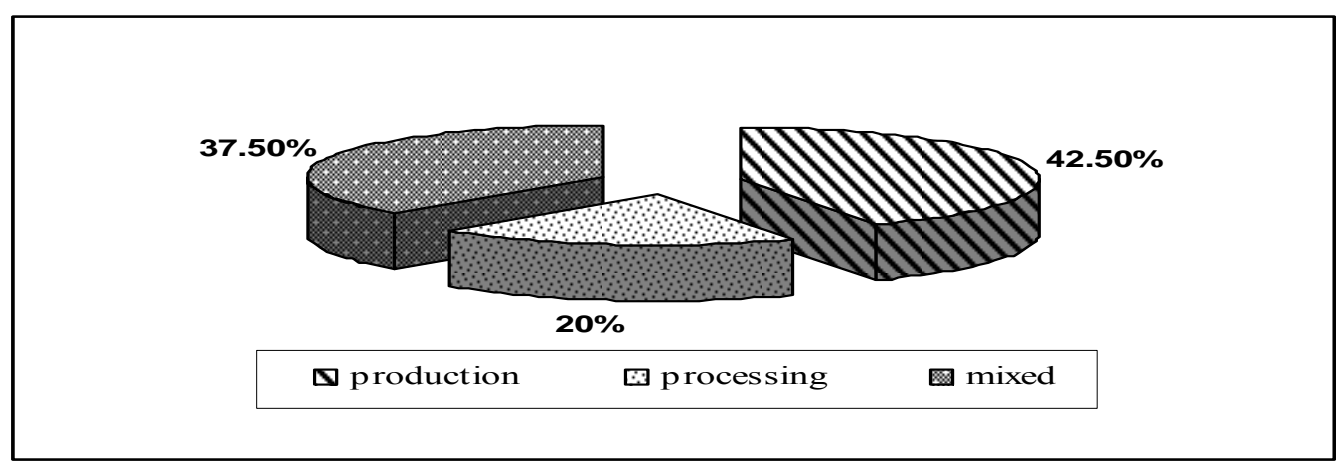

Figure 1. Interviewees according to the type of business of enterprise 


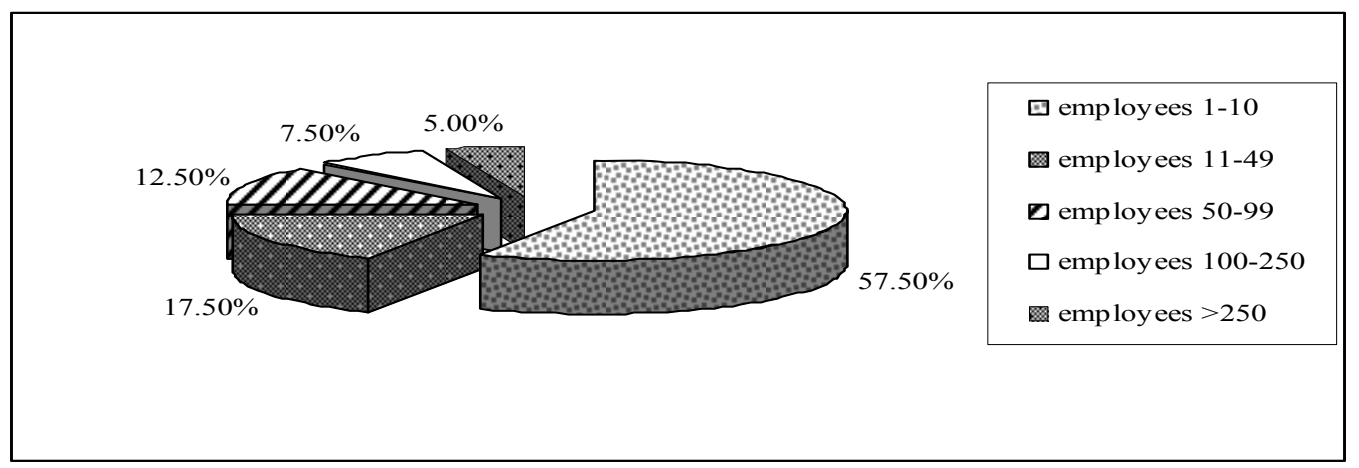

Figure 2. Interviewees according to the number of employees in the enterprise

According to the number of employees working in each enterprise, most of the businesses are micro-enterprises (with up to 10 employees), which comprise $57.5 \%$, and along with small enterprises (11-49 employees) they make $75 \%$ of the overall number (Fig. 2). Medium-size enterprises (50-99) are relatively few $-12.5 \%$, and the remaining $12.5 \%$ are for big and very big companies. The results show that the restructuring and congestion of agricultural enterprises is indeed a slow process.

The access to timely and detailed information about the EU requirements for enterprises producing and trading with food items is an essential factor for successful restructuring and adaptation to the Common European Market. Companies' information security lies within the activeness of the company itself but also within the characteristic features of the information environment - accessibility, comprehensiveness, regularity (Ковачева, 2008b).

It is a worrying fact that $55 \%$ of the interviewees admit that they are only partly aware of the EU requirements for the introduction of classification systems for agricultural products and $10 \%$ state that they have no knowledge whatsoever (Fig. 3 ). One of every three gives an affirmative answer to the question which might be indicative of willingness or readiness for those systems to be implemented.

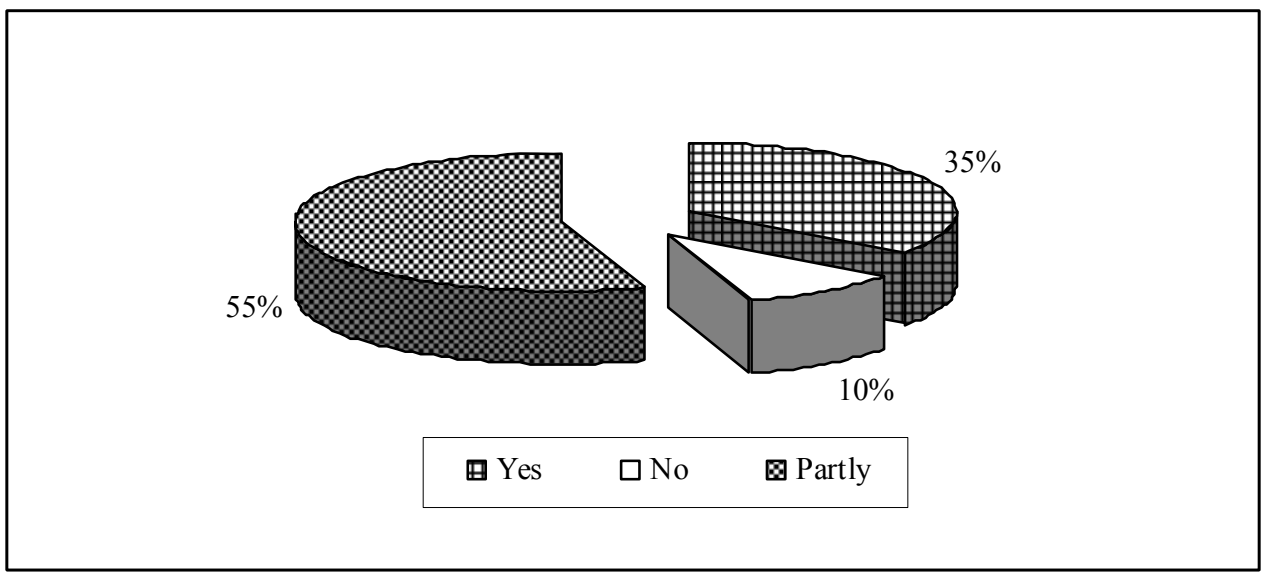

Figure 3. Degree of informity in accordance with regulations

Interviewees' opinions, reflected in Table 1, show preferences in terms of the source of information. The table also points out the relative importance of each of these sources. An average of 4.3 sources are ticked on questionnaire handouts in accordance with their accessibility and relevance. For the 16 sources of information listed in the questionnaire, 171 answers have been received.
The greatest number of all the answers $-17.5 \%$, speaks in favour of Internet sources.

The results display a desire for a quick access to information shared by almost $1 / 5$ of the interviewees. The second place in accordance with the number of answers received - $22(13 \%)$, and the first place in terms of a degree of importance is held by the ministries in charge - the Ministry of 
Agriculture and Food, the Ministry of Economics, the Ministry of Regional Development, the Ministry of Health Care. The search for these institutions could be explained with the relevance of their information, as well as the direct access to existing requirements and regulations and different financial instruments. In close proximity in their significance are two other state institutions - the Regional inspection for health protection and envi- ronmental safeguard and the State veterinary control, each with $12 \%$ and $10 \%$ of the answers respectively. The forth place according to the number of answers (18) and in significance is for friends and partners. These are preferable sources when it comes to trust and free information, but these are also ample opportunities for discussion of information and undertaking of tangible measures.

Table 1

Information resources

\begin{tabular}{|c|c|c|c|c|c|c|c|}
\hline \multirow[t]{2}{*}{ № } & \multirow[t]{2}{*}{ Information sources } & \multicolumn{5}{|c|}{ Degree of importance } & \multirow[t]{2}{*}{ Total } \\
\hline & & I & II & III & IV & V & \\
\hline 1 & Ministry in charge & 12 & 4 & 4 & 2 & - & 22 \\
\hline 2 & Branch organization & 2 & 3 & 4 & - & - & 9 \\
\hline 3 & Internet & 6 & 3 & 8 & 8 & 5 & 30 \\
\hline 4 & State veterinary control & 5 & 7 & 4 & - & 1 & 17 \\
\hline 5 & Regional inspection for health protection and environmental safeguard & 4 & 8 & 6 & 2 & - & 20 \\
\hline 6 & Agencies and associations & 2 & 1 & 1 & 2 & - & 6 \\
\hline 7 & Universities and institutes & - & - & 1 & 2 & - & 3 \\
\hline 8 & Regional and municipal administrative services & 4 & 1 & 1 & 7 & 2 & 15 \\
\hline 9 & Guides and handbooks & 4 & - & - & 1 & 1 & 6 \\
\hline 10 & Exhibitions, conferences and seminars & 1 & 4 & 4 & 4 & - & 7 \\
\hline 11 & Specialized courses and training & - & 2 & 1 & - & - & 3 \\
\hline 12 & Consulting agencies & 1 & - & 2 & - & - & 3 \\
\hline 13 & Specialized laboratories & - & - & 1 & 1 & 3 & 5 \\
\hline 14 & Friends and partners & - & 3 & 1 & 7 & 7 & 18 \\
\hline 15 & Other & - & - & - & 1 & 4 & 5 \\
\hline
\end{tabular}

Another valued resource (9\%) is that of the counseling services in regional and municipal administrations. They offer an access to standards, requirements, projects and expert advice. Somewhat underestimated in interviewees' answers remain branch organizations; exhibitions, conferences and seminars; agencies and associations; guides and handbooks. The very small interest in specialized laboratories, specialized courses and training, universities, institutes and consulting agencies is more than alarming. At the same time state institutions, branch organizations, specialized agencies, institutes and laboratories do very little to engage themselves in quick and effective exchange of information, in organizing training and counseling programs to facilitate the implementation of the EU requirements.

To the question - What sort of information concerning the qualification and classification sys- tems you consider insufficient - the interviewees once again have more than one answer (Fig. 4).

The information regarding product certification and international standards is of the highest interest for $27 \%$ of them. This reveals people's concern with possibilities for product realization on international markets.

The second important sort of information seems to be the one related to hygiene and food safety $-19.2 \%$. With equal degree of importance is the need for information on ecological requirements and quality management $-15.4 \%$. A portion of the interviewees $(11.5 \%)$ believe that they possess sound knowledge of the EU regulation requirements and that they receive enough information. The percentage of those interested in food labeling requirements and other information is relatively small $-5.7 \%$. 


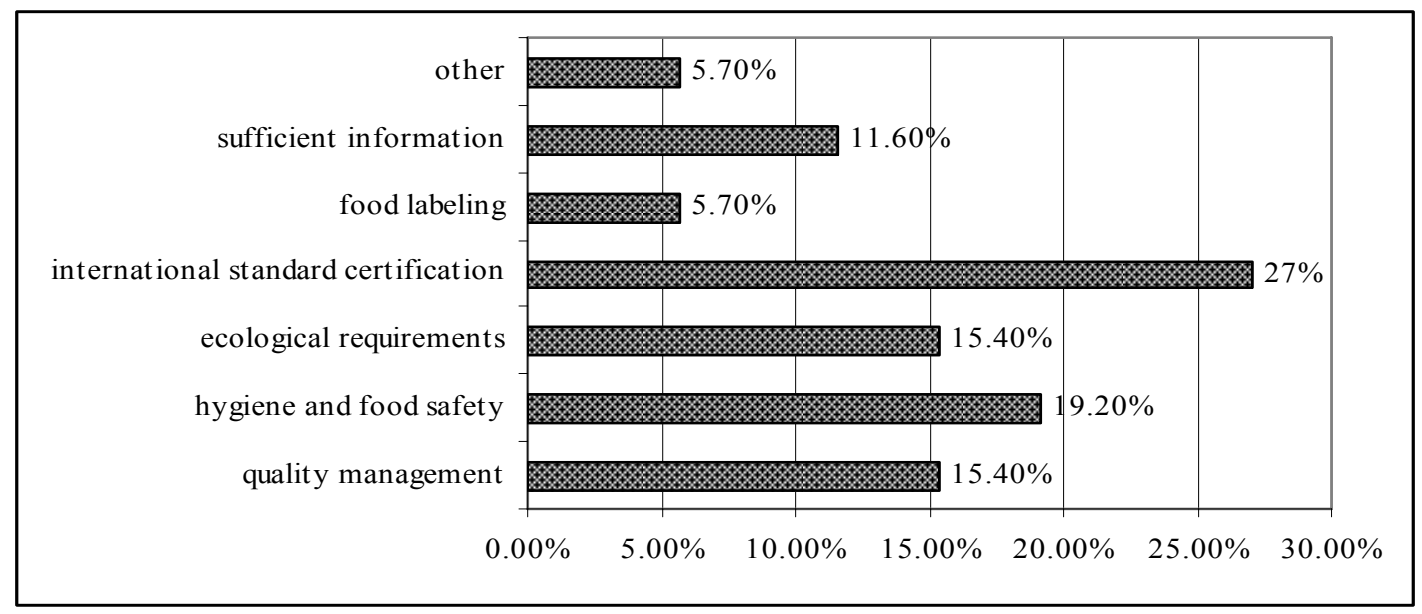

Figure 4. Types of insufficient information.

Companies' information security is largely predetermined by who is directly engaged in this activity. The prevailing answers $-70 \%$, indicate that this is the company's manager. The remaining replies are distributed almost evenly $-10 \%$ for specialist involvement and for staff involvement each, and $5 \%$ for outside consultant and for other individual responsible. The results are in conformity with interviewees' insufficient knowledge of regulations described above. The need for an information specialist is made evident. Yet, microenterprises and small businesses, which comprise the majority in the case of study, can hardly afford to hire such specialists and this is an impediment to their timely and complete informative awareness.

\section{CONCLUSION}

Representatives of micro- and small enterprises, which comprise $75 \%$ of the interviewees, are not well informed of the EU regulations and requirements for the classification of agricultural products.

The Ministries in charge, as well as the state institutions, which are the most valued sources of information, do not seem willing to engage themselves in quick and effective exchange of informa- tion, in organizing training and counseling programs to facilitate the implementation of the EU requirements. Meanwhile, public organizations and specialized research institutes remain highly underestimated as information sources.

The desire for competitiveness and international market realization is impeded by the lack of a specialized information resource for agricultural produce enterprises.

\section{REFERENCES}

[1] Kovacheva T. S. (2008a): European Policy for Organization and Control of the Food Safety in Bulgaria, Agricultural Economics and Management, 53, 2, 16-26.

[2] Kovacheva T. S. (2008b): Resources and Barriers for Introduction of EU Standards in the Enterprises from the Dairy Sector, Agricultural Economics and Management, 53, 5, $15-21$.

[3] Koteva N., H. Bachev, M. Risina, M. Mladenova (2009): Assessment of Impact of EUCAP on Farms, Agricultural Economics and Management, 54, 3, 16-25.

[4] Malamova N. (2009a): Social and Economic Effects of the Introduction of the European Requirements for Food Safety in the Meat Industry Enterprises. Agricultural Economics and Management, 54, 1, 19-28.

[5] Malamova N. (2009b): Resources of Enterprises from the Meat Industry to Abide with the EU Standards for Food Safety. Agricultural Economics and Management, 54, 2, 18-26. 